\title{
Use of Molecular Markers and Scientific Ability
}

\section{Asfaw Adugna*}

Maize Breeder, Advanta Seed International, P.O. BOX 1085, Adama, Ethiopia

*Corresponding author: Asfaw Adugna, Maize Breeder, Advanta Seed International, P.O. BOX 1085, Adama, Ethiopia, Tel: +971 45516394; E-mail: asfawadugna@yahoo.com

Rec date: July 04, 2015, Acc date: July 20, 2015, Pub date: July 22, 2015

Copyright: $\odot 2015$ Adugna A. This is an open-access article distributed under the terms of the Creative Commons Attribution License, which permits unrestricted use, distribution, and reproduction in any medium, provided the original author and source are credited.

\section{Commentary}

This paper is aimed at giving comments to some institutions, which in their molecular biology/ genetics related job postings indicate that the incumbent must have very good knowledge on a specific marker.

The use of molecular markers as basic and applied research tools in plant and animal biology have been used from decades. Various types of markers have been developed and used with different modifications all the time. They have been continuously changing with the advent of new technologies supporting them. Christian [1] summarized them as protein variants (allozymes), DNA sequence polymorphism and DNA repeat variation. The use of marker systems began with detecting variations at the level of bigger molecules (allozymes) followed by hybridization based DNA markers (such as RFLPs), and PCR based markers. From a relatively larger DNA fragments, now the field has progressed to identification of single base sequence variations (mutations) using next generation sequencing approaches. These latter approaches enable high throughput whole genome (both chromosomal and extra-chromosomal DNA) scans, which are more advanced and more efficient to date. The results of quite a large number of research works on application of molecular markers covering almost the entire living organisms have been published in internationally reputed publications (journals and books). The design and development of different DNA and protein based markers is the primary step before their application. Chenuil [2] categorized the criteria of choosing molecular markers into three as: (1) the level of variability, (2) the nature of the information (e.g. dominance vs. codominance, ploidy) and (3) the availability of laboratory equipment and experience of the scientist.
The technologies have been applied by scientists in the biological sciences including different fields of genetics, molecular biology, plant and animal breeding, evolutionary biology (both micro and macro), ecology, plant and animal genetic resources conservation, etc. With the rapid advancement of new laboratory techniques, it is becoming difficult for every laboratory to keep on trying the same. As a result, it is becoming more effective and efficient to do this through outsourcing by designated laboratories.

A person who has experience on application of some kind of the available molecular markers on a species is assumed to have adequate knowledge and the experience on the subjects of genetics and molecular biology techniques. In turn, this person is expected to easily understand and update himself/herself with the newly emerging molecular tools as well. However, very recently, for instance it is not uncommon to read in the job postings "the incumbent must have strong background on use of next generation sequencing or genotyping by sequencing, etc." as a requirement. This kind of job postings narrows the competition dimension and precludes potential high caliber candidates out of the competition track and whether the same is valid for identifying potential candidates for the institutions remains open ended question.

\section{References}

1. Christian S (2004) The evolution of molecular markers - just a matter of fashion? Nature Reviews Genetics 5: 63-69.

2. Chenuil A (2006) Choosing the right molecular genetic markers for studying biodiversity: from molecular evolution to practical aspects. Genetica 127: 101-120. 